\title{
Identification of the hot spots phenomenon in brakes by using a thermal imaging camera
}

by W. Sawczuk*

\author{
*Poznan University of Technology, 60-965, Piotrow 3, Poznan, Poland, wojciech.sawczuk@put.poznan.pl
}

\section{Abstract}

A long operation of the brake pads of the brake disc causes uneven wear of the friction surface. This applies both to the friction pads of organic material and from sintered metal. For larger braking power is the reason for overheating the blade, resulting in varying temperature distribution on the brake disc cooperating with the friction pad. The first study of this phenomenon has shown that it is highly speed-dependent braking. Therefore, it was observed during the train's braking from a speed of $300 \mathrm{~km} / \mathrm{h}$. At these speeds the brake disc there are known. Hot spots between which are areas with a substantially lower temperature. However, in areas of high temperatures it occurs following the formation of the protrusions due to the expansion of the target material. This phenomenon is further enhanced during each rotation of the disc, while on each bulge of material stresses acting on each surface of the friction pad. Occurring grooves on the facing (the space between the surfaces of friction) have proved insufficient to absorb the heat produced during braking. They take a small part of the thermal energy, which on the face have areas with different temperatures, $100{ }^{\circ} \mathrm{C}$ at the periphery of the disc 800 and $900{ }^{\circ} \mathrm{C}$ protrusions. This phenomenon is very complicated because it involves in addition to the properties of the material for brake discs presented and described dependency of the breaking function of temperature. Thus, many manufacturers brake disc determines the maximum mean temperature of the disc at $400{ }^{\circ} \mathrm{C}$ in cooperation with the organic friction pad and $550{ }^{\circ} \mathrm{C}$ in cooperation with the pad of sintered metal. Type of braking understood speed beginning of braking pressure to the brake disc pads and the mass of the slowdown and the strength properties of the target material impact on the number of hot spots on the disc, ie. The distance between hot spots. In order to eliminate the phenomenon, the manufacturers of friction pads modify the shape of the contact surface pads of brake discs to ensure even distribution of pressure on the dial. However, during the long service there is a phenomenon of laying a liner with respect to the brake disc, the reasons for the backlash in the mechanism of the brake lever which, due to wear of the brake disc itself. Then, in some cases, a phenomenon arises hotspots. Cladding without causing the phenomenon is facing divided into several friction elements hinged. This solution will ensure even distribution of the pressure of all the friction elements on the shield throughout the life of the pad. As a result, the brake disc does not tend to create "hot" areas that are the reason the formation of bulges in the material of the disc.

The article presents the possibility of using the thermal imaging camera studies disc brakes in order to identify the phenomenon of hot spots. The results allow to evaluate the temperature distribution on the brake disc in which there is a tendency to create hot spots.

\section{Introduction}

In rail vehicles, both trains, trams and metro, a disc brake is the primary friction brake (Fig. 1a). Furthermore, only in traction vehicles, the electrical traction units or trams the disc brake cooperates with the electrodynamic brake (ED).

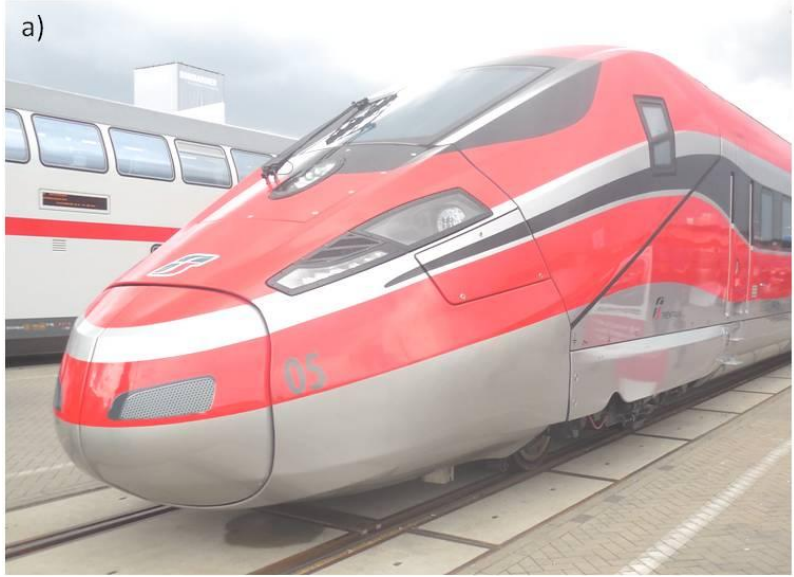

b)

Fig. 1. Italian fast train Frecciarossa 1000: a) view of the train, b) view of the bogie of train with brake discs mounted on axle wheelset [11] 
In the case of rolling cars there is only a disc brake. It sometimes also cooperates with the rail brake which in this case is a safety. Depending on the design speed of the wagon, on the axle of the wheelset two, three or even four brake discs are mounted (Fig. 2b).

Long operation of disc braking systems both with pads made of organic materials and sintered metal causes an irregular wear of the friction pads surface. Consequently, there is an irregular pressure distribution of friction pads to the brake disc, which leads to hot spot phenomenon.

a)

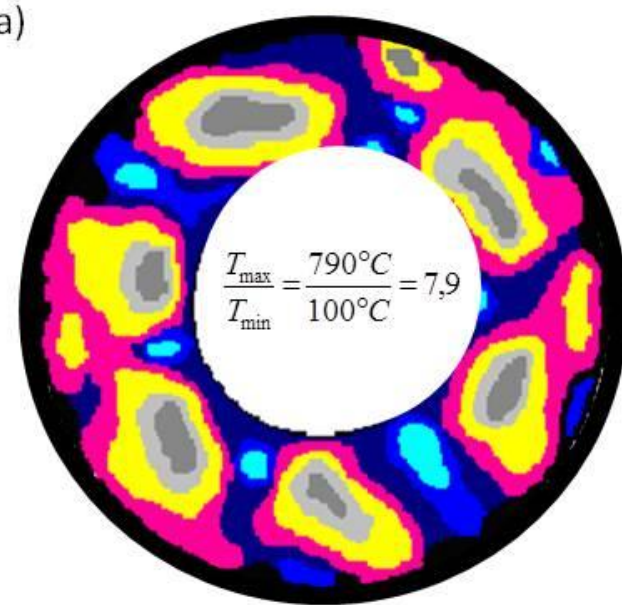

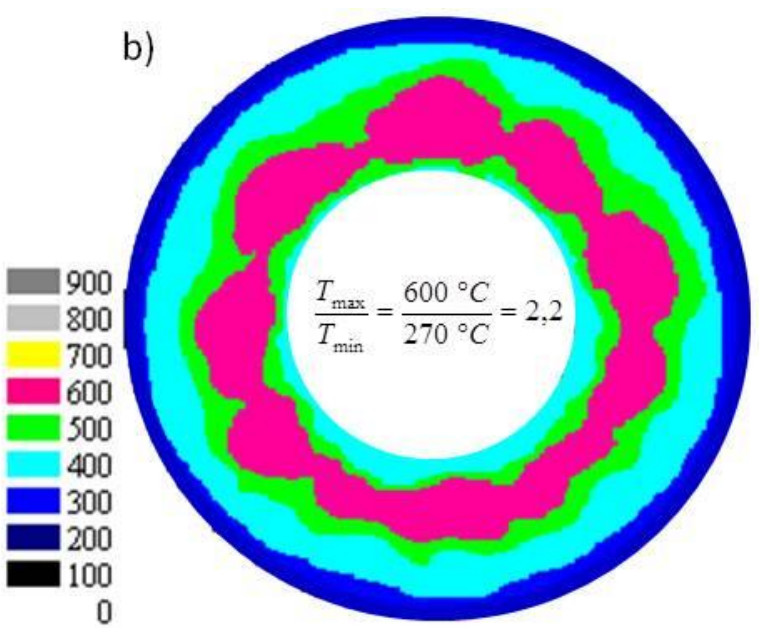

Fig. 2. The temperature distribution on the brake disc cooperates with a pad material: a) an organic, b) sintered

The phenomenon of hotspots or hot areas occurs most often when braking with a strong emphasis of pad to the disc. Figure 2 shows the temperature distribution on the brake disc that cooperates with the pad made of sintered metal during braking from the speed of $300 \mathrm{~km} / \mathrm{h}$. Then, on the disc appear Hot spots between which there are areas with a substantially lower temperature. In the areas of high temperature the protrusions are created. They appear due to the expansion of the disc material. This phenomenon is further enhanced at every rotation of the disc. This situation happen when on each bulging of the material work pressures of the individual friction pad. Grooves (spaces between the friction surfaces that appear on the pad are insufficient to absorb the heat produced during braking. They receive a small part of the thermal energy, which on the disc have areas with different temperatures, $100{ }^{\circ} \mathrm{C}$ at the periphery of the disc 800 to $900^{\circ} \mathrm{C}$ and the protrusions [13]. The increase in temperature (hot spots) is calculated from equation (1):

$$
H S=\frac{T_{\max }}{T_{\min }}=\frac{435,8^{\circ} \mathrm{C}}{187,3^{\circ} \mathrm{C}}=2,32
$$

a)

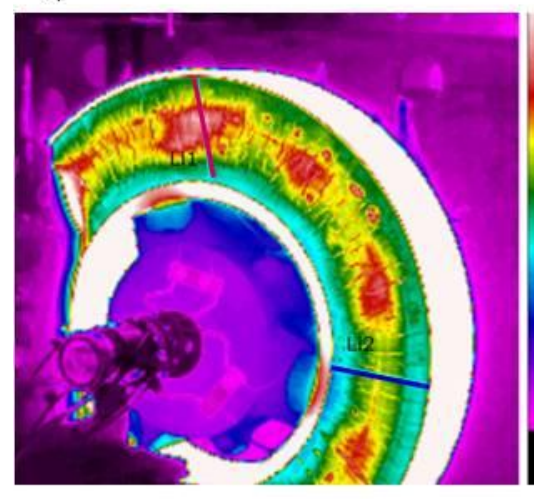

$431^{\circ} \mathrm{C}$
400
300
200
100
0
$-87,8$

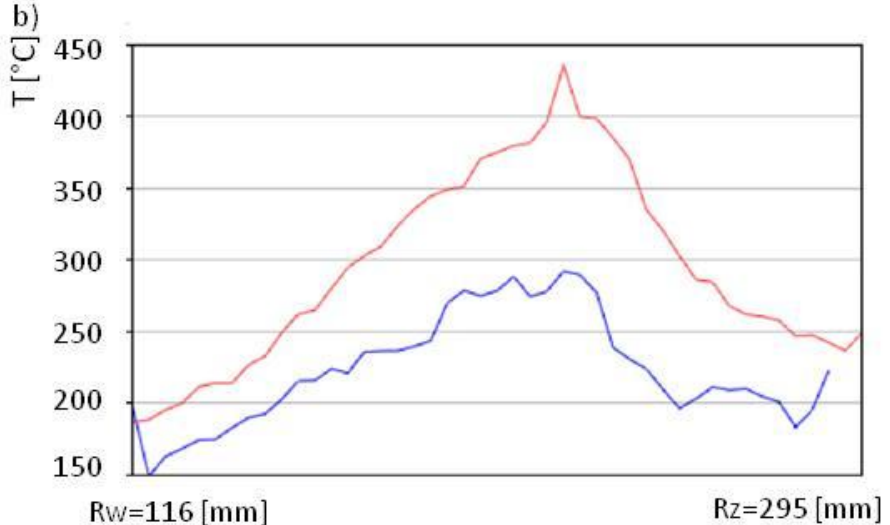

$\mathrm{R} w=116[\mathrm{~mm}]$
$\mathrm{Rz}=295[\mathrm{~mm}]$

- $\mathrm{L} 1 \mathrm{Tmin}=187,3, \mathrm{Tmax}=435,8 \mathrm{Tavg}=294,2\left[{ }^{\circ} \mathrm{C}\right]$

- $\mathrm{L} 2 \mathrm{Tmin}=149,3, \mathrm{Tmax}=292,5 \mathrm{Tavg}=223,7\left[{ }^{\circ} \mathrm{C}\right]$

Fig. 3. The temperature distribution on the brake disc after braking from a speed of $v=200 \mathrm{~km} / \mathrm{h}$ with pressure contact $N=28 \mathrm{kN}$ and weight to brake $M=6.7 \mathrm{t}$ : a) thermographs with marked lines $L 1$ to hot spots and $L 2$ between the hot spots, b) temperature distribution within the target on the lines $L 1$ and $L 2, R w$-inner radius, $R z$-outer radius

Figure 3a) shows an infrared image of railway brake disc after braking from a speed of $\mathrm{v}=200 \mathrm{~km} / \mathrm{h}$, where some hot areas were observed. Figure $3 b$ ) shows the temperature distribution on the radius of the disc in place where 
the hot areas appear. In order to observe the temperature rise for the hot spot on the radius of the disc, the graph presents the temperature distribution in another place without the hot area. Observation of the temperature distribution on the disc by using thermal imaging camera has shown that hot spots appear in the final braking phase and lasts few seconds to the stop time.

In extreme cases the temperature rise on a hot spot in accordance with [13] may amount to 8.8 relatively to the area with the lowest temperature. However, such high values are obtained when braking with pads made from sintered metal. The rest of the article shows the increases in temperature (hot spots) on the brake disc during braking with organic pads. It should be pointed out that the phenomenon of hot spots is widely considered by many researchers who deal with the both brake systems and the friction clutches of the means of transport $[1,2,5,8,16]$. Number of papers presents the results of studies that allow to identify the phenomenon in respect of the location and number of hot spots on the brake disc $[5,6]$. Part of the articles present the simulation results conducted at the ANSYS environment also paying attention to the phenomenon of hot spots as the papers $[3,4,7,14,15]$.

\section{The research methodology}

Research in the field of railway braking process of the disc brake evaluation was conducted on a brake position at the Institute of Rail Vehicles TABOR in Poznan. The position allows conducting a test of the block brake and the disc brake. The proving reflects the actual conditions that occur during car or traction vehicle braking. The study covered a disc brake, consisting of the brake disc with outer diameter of $590 \mathrm{~mm}$ and with the ventilation blades and a set of the friction pads type 175 FR20.H.2. with a thickness of 35 (new brake pad), 25 and $15 \mathrm{~mm}$ (wear brake pads).

The research of the brake disc temperature was conducted by using six thermocouples installed on the disc, three on each side of the disc. During the research the IR camera was also used.
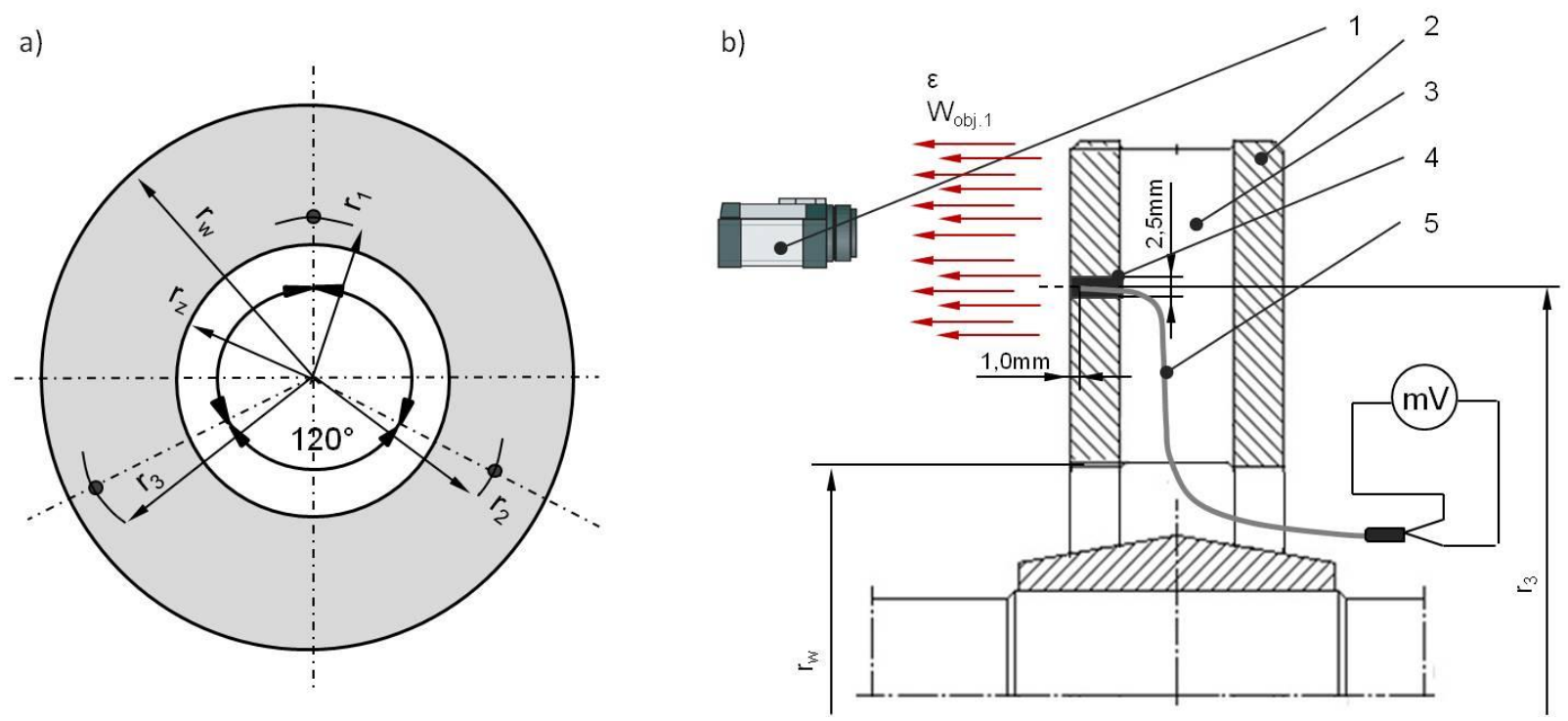

Fig. 4. Research methodology of the brake disc temperature: a) view of thermocouples distribution on the brake disc in accordance with the [9], b) Scheme of the research methodology, 1 - IR camera, 2 - friction ring, 3 - ventilating blade 4 - elastic bush, 5 - TP-213K-a-200-200 thermocouple, $r_{w}$ - inner radius, $r_{3}$ - thermocouple assembly ray, $\varepsilon$ emissivity, $W_{\text {obj. }} 1,2$ - radiation of the object 1,2

The holes for thermocouples $(\varnothing 2,5 \mathrm{~mm})$ were drilled at $120^{\circ}$ on three rays of the disc, $r_{1}=r_{w}+1 / 4\left(r_{z}-r_{w}\right), r_{2}=r_{w}+$ $1 / 2\left(r_{z}-r_{w}\right)$, and $r_{3}=r_{w}+3 / 4\left(r_{z}-r_{w}\right)\left(r_{z}\right.$ - outer radius of the disc, $r_{w}-$ radius of the inner disc), as shown in Figure $4 a$.

Thermocouples against the friction surface of the disc were embedded $1 \mathrm{~mm}$ in the disc so that the ends of thermocouples, according to [9] were not destroyed by the friction pad. In the holes which are close to the outer diameter of the disc, the thermocouples with the longest operating part were installed (TP-213K-a-300-200 thermocouples). On the other rays TP-213K-A-200-200 thermocouples were installed. On the other side of the disc are holes which have been shifted by $60^{\circ}$ to the first side in order to avoid overlapping of thermocouples. The method of temperature measurement by using thermocouples and an infrared camera is shown in Figure $4 \mathrm{~b}$. In the position test, which is not a requirement of UIC 541-3 card, the FLIR thermal imaging camera E60 was used. It was used for the qualitative assessment of the braking process.

The position tests for the railway brakes were carried out in accordance with one of the programs contained in the UIC 541-3 card. Parameters for the $2 \mathrm{~B}$ program, of the tests were as follows:

- Pressure of pad to the disc (pressure contact) $p=25$ and $36 \mathrm{kN}$,

- Beginning of braking speed: $v=120,160$ and $200 \mathrm{~km} / \mathrm{h}$,

- The braking mass per one disc: $M=5.7 \mathrm{t}$.

- The temperature of the disc at the beginning of braking $\mathrm{T}=50^{\circ} \mathrm{C}$. 
Table 1. The values of the thermal imager configured for stand tests disc brake

\begin{tabular}{|l|l|}
\hline Emissivity & 0.97 \\
\hline The reflected apparent temperature & $18^{\circ} \mathrm{C}$ \\
\hline Distance & $2 \mathrm{~m}$ \\
\hline Relative humidity & $50 \%$ \\
\hline Air temperature & $18^{\circ} \mathrm{C}$ \\
\hline The temperature of the external optical system that it & $20^{\circ} \mathrm{C}$ \\
\hline
\end{tabular}

The study was divided into two phases. In the first stage, due to the lack of information about the real value of the emissivity factor, the coefficient $\varepsilon=0.97$ was entered to the camera because of the fact that the brake disc was coated with a black heat-resistant paint on its thickness, including ventilation ducts. Later the temperature was read from these surfaces. Other parameters like temperature of the atmosphere and reflection, humidity and the distance from the object (Disc) were entered to the camera and the values were shown in Table 1. At this stage, thermal images of the disc brake were recorded on the brake position, and the temperature of the friction surface of the disc with 6 thermocouples was recorded simultaneously. Zdjęcia termowizyjne wykonano w chwili zatrzymania mierząc zarówno termoparami jak $\mathrm{i}$ kamerą termowizyjną - temperaturę końca hamowania Tk. Thermal images were taken in the stop time, measuring Tk the temperature of the end of braking by the use of thermocouples and thermal imaging camera.

In the second stage, thermal images were modified in FLIR Tools software. Then on the disc as shown in Figure 5 , on the working surface of the disc (contact surface with friction pad), an ellipse was marked, calculating the average value of the temperature from the polished surface. Then, based on the results of the temperatures recorded by the thermocouples attached to the friction surface, the emissivity value was changed in FLIR Tools software. It was made to get the same temperature of the disc friction surface as in the case of thermocouples. This is a colorimetric method for determining the coefficient of emissivity described inter alia in [10,12].
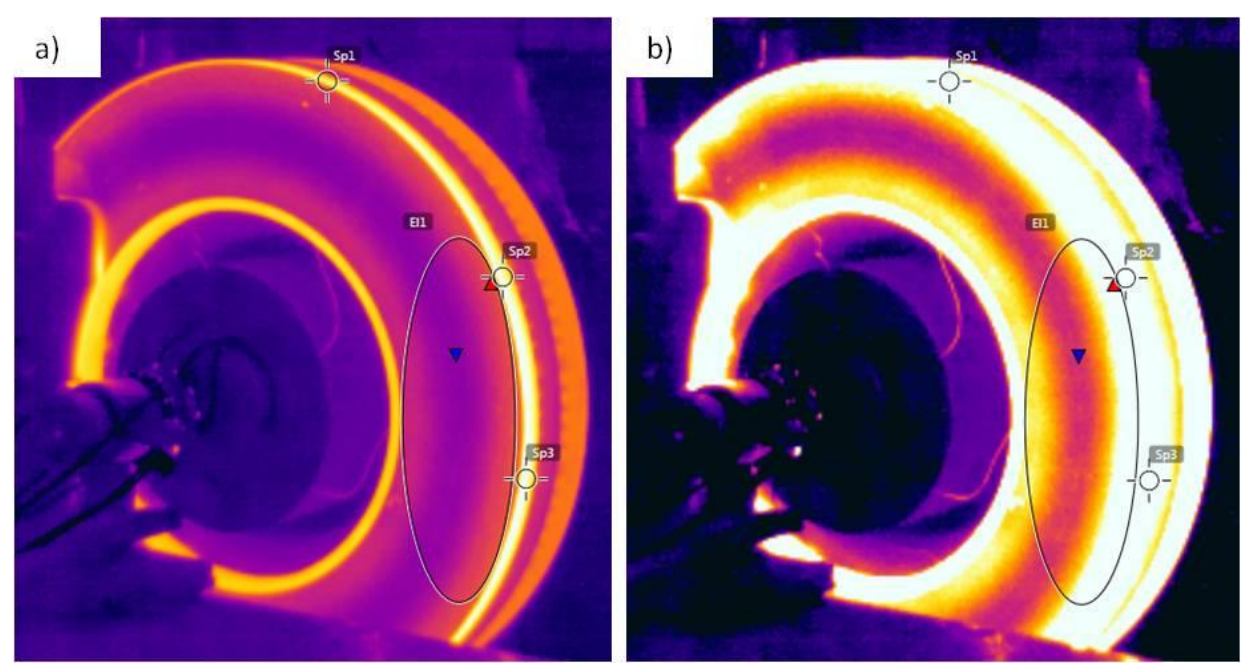

Fig. 5. Thermographic image of the FLIR E60 camera generated in the FLIR Tools: a) for 0,97 value of the emissivity, b) for emissivity amended

On the basis of this studies it was found that after 40 brakings the coefficient value stabilized at the value of 0.113 , obtained from the arithmetic mean of 30 brakes i.e., calculated from the 41 brake to the 70 brake.

\section{The research results}

Figure 6 shows the thermal images after braking from a speed of 120, 160 and $200 \mathrm{~km} / \mathrm{h}$ with a pressure of 25 and $36 \mathrm{kN}$. For better observation of the hot spot phenomenon each span was changed. The evaluation of the temperature distribution of the brake disc after determining the emissivity, was performed in Flir Reporter software. On the infrared image with the visible friction surface of the disc brake, three line segments - from the inner radius of the brake disc to the outer radius was applied. This is presented in Figure 3a). Then on the graphs of temperature distribution (as shown in Figure $3 \mathrm{~b}$ ) the maximum and minimum were observed. All the line segments L1, L2 and L3 were led through three selected hot spots. 
a)
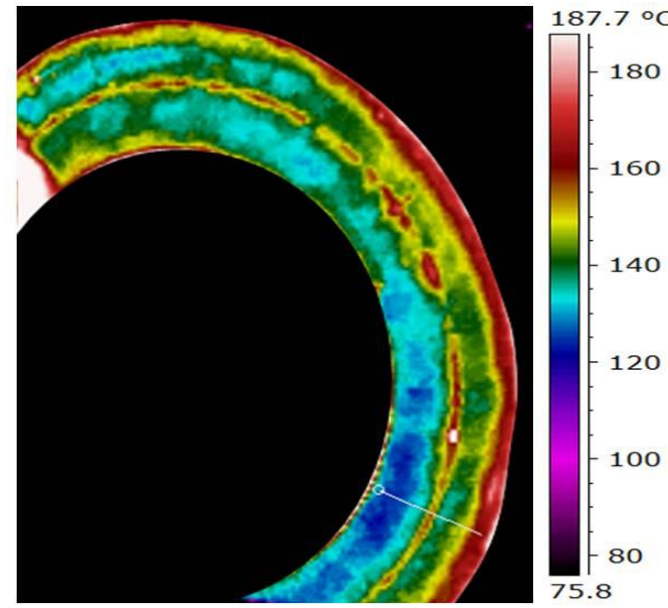

b)

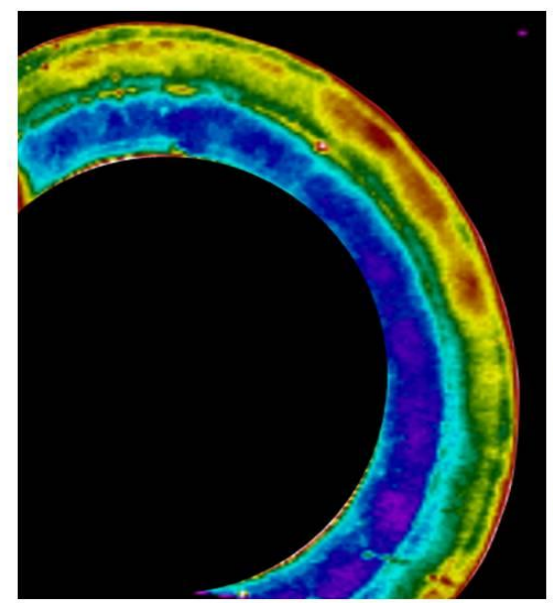

$315.8^{\circ} \mathrm{C}$

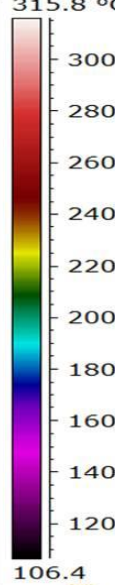

C)

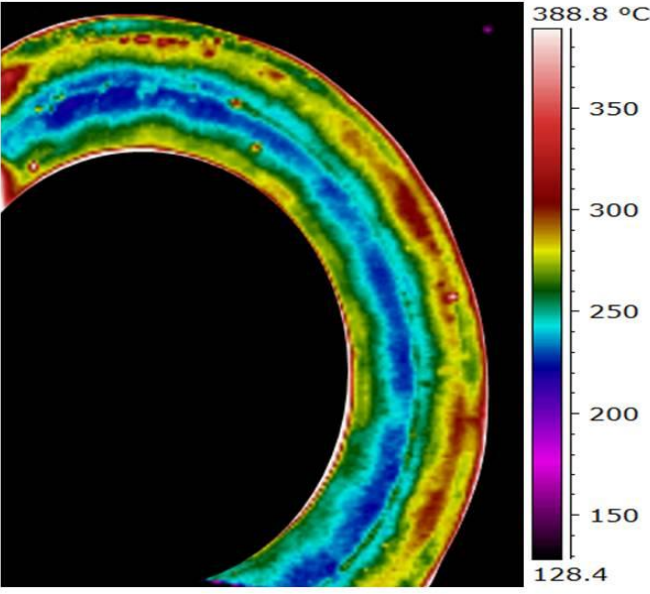

d)
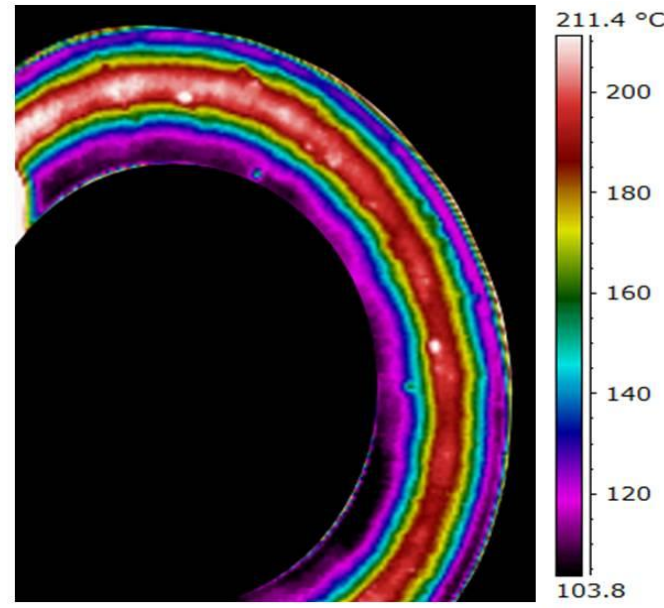

e)

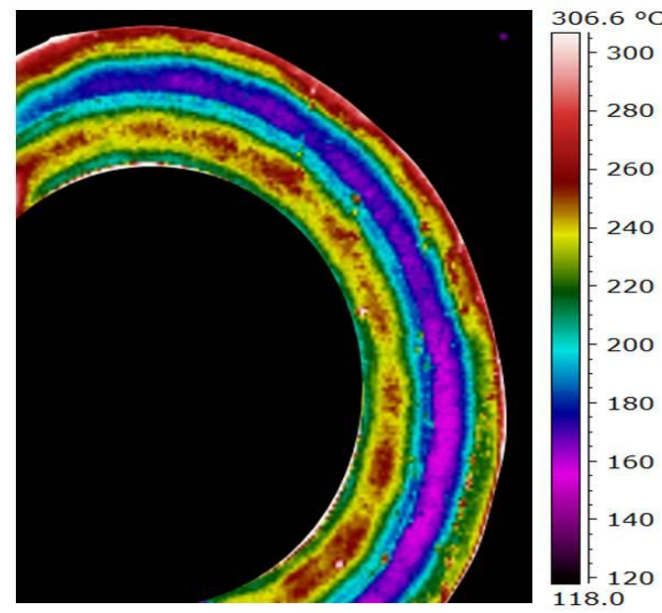

f)

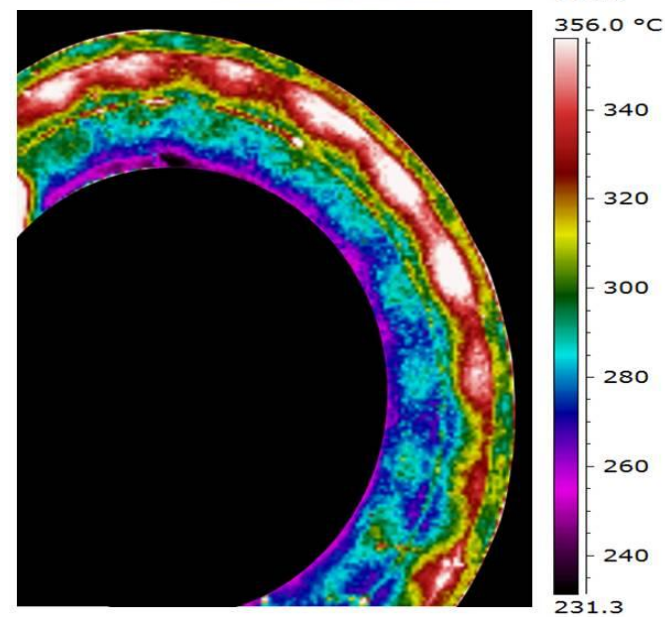

Fig. 6. Thermal gradients classification illustrated by thermographs from several speed for the two pressure contact: a) $v=120 \mathrm{~km} / \mathrm{h}, \mathrm{N}=25 \mathrm{kN}$, b) $v=160 \mathrm{~km} / \mathrm{h}, \mathrm{N}=25 \mathrm{kN}$, c) $v=200 \mathrm{~km} / \mathrm{h}, \mathrm{N}=25 \mathrm{kN}, \mathrm{d}) v=120 \mathrm{~km} / \mathrm{h}, \mathrm{N}=36 \mathrm{kN}$, e) $v=160 \mathrm{~km} / \mathrm{h}, N=36 \mathrm{kN}$, f) $v=120 \mathrm{~km} / \mathrm{h}, \mathrm{N}=25 \mathrm{kN}$

Figure 7 and 8 shows the value of the average maximum and a minimum temperature defined form linear segments between the inner and outer radius of the brake disc, passing through the hot spots. Then, by using the equations (1). The values of temperature rise in the hot area was calculated. In the case of Figure 8a (braking from a speed of $120 \mathrm{~km} / \mathrm{h}$ ), there was no hot areas on the disc and only for one heat disc a maximum, minimum temperature and $\Delta \mathrm{T}$. 
a)

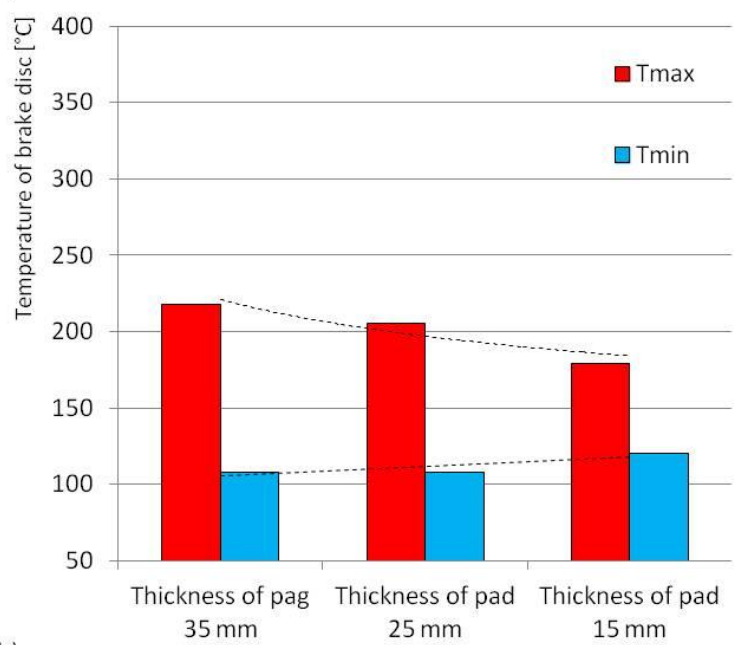

b)
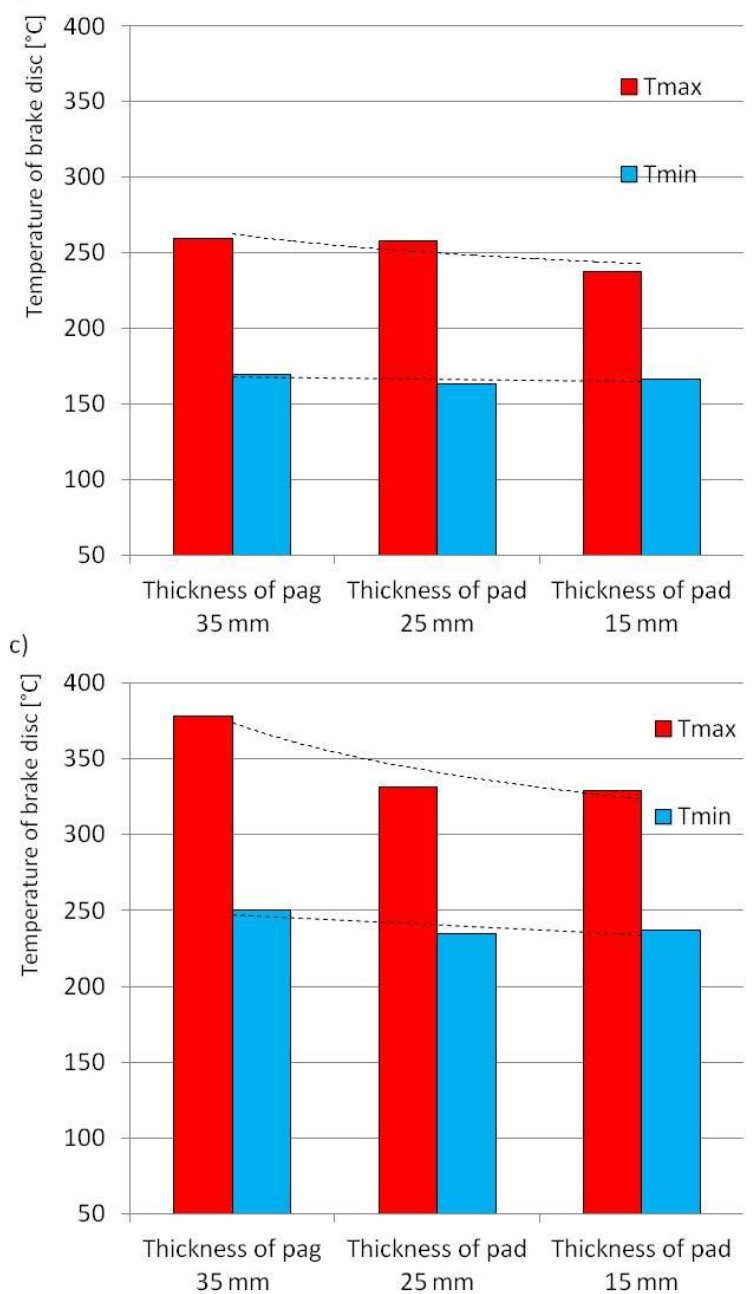
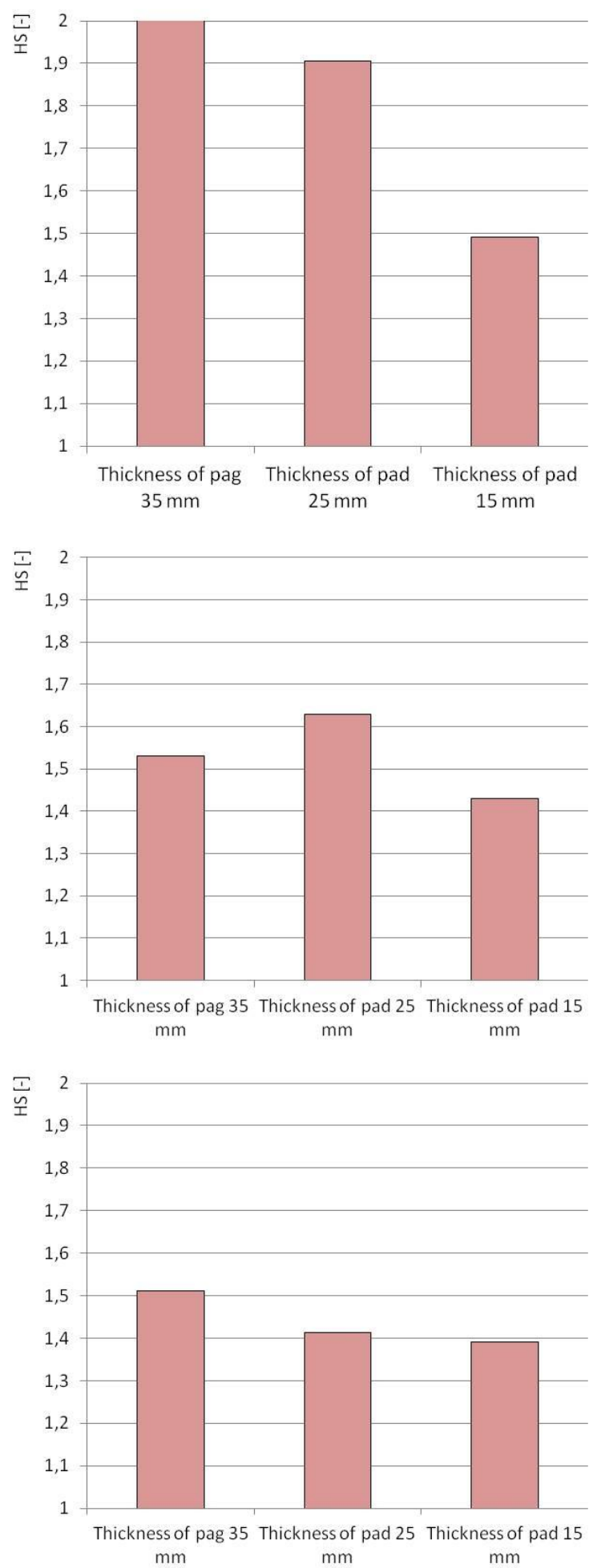

Fig. 7. The temperature difference in the radius of the brake disc and the temperature rise (HS-hot spots) after braking with pressure contact $N=36 \mathrm{kN}$ for three thickness of brake pads: a) speed braking $v=120 \mathrm{~km} / \mathrm{h}, \mathrm{b}$ ) speed braking $v=160 \mathrm{~km} / \mathrm{h}, \mathrm{c})$ speed braking $v=200 \mathrm{~km} / \mathrm{h}$ 

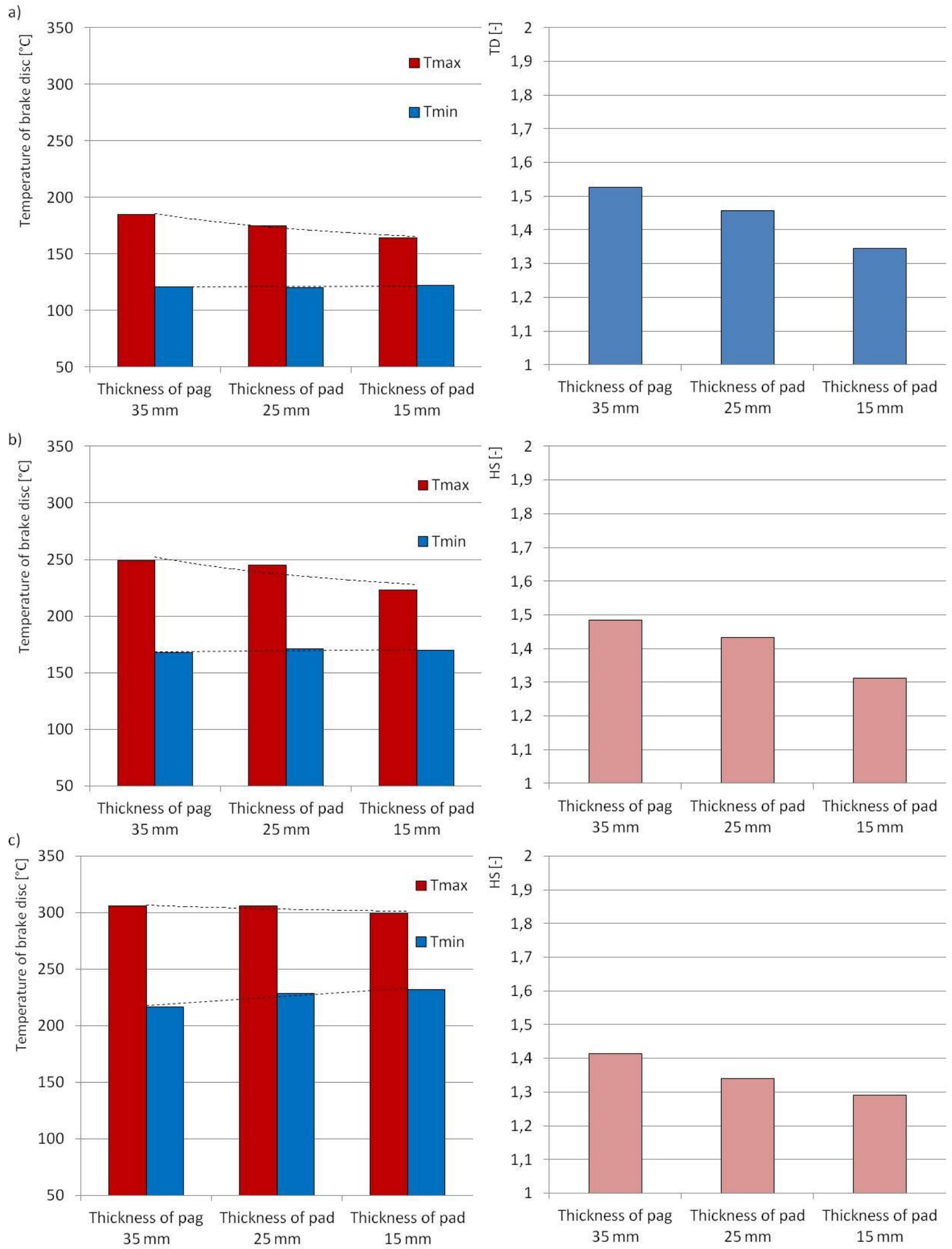

Fig. 8. The temperature difference in the radius of the brake disc and the temperature rise (TD-without hot spots, only hot band, HS-hot spots) after braking with pressure contact $N=25 \mathrm{kN}$ for three thickness of brake pads: a) speed braking $v=120 \mathrm{~km} / \mathrm{h}$, b) speed braking $v=160 \mathrm{~km} / \mathrm{h}, \mathrm{c}$ ) speed braking $v=200 \mathrm{~km} / \mathrm{h}$ 
Figure 9 shows collective specification of the disc temperature rise in the place of hotspots for three analyzed braking speeds $(120,160$ and $200 \mathrm{~km} / \mathrm{h})$, three thicknesses of the friction pads $(35,25$ and $15 \mathrm{~mm})$ and two pressures of the pads to the disc ( 25 and $36 \mathrm{kN}$ ) which were performed during braking.

a)

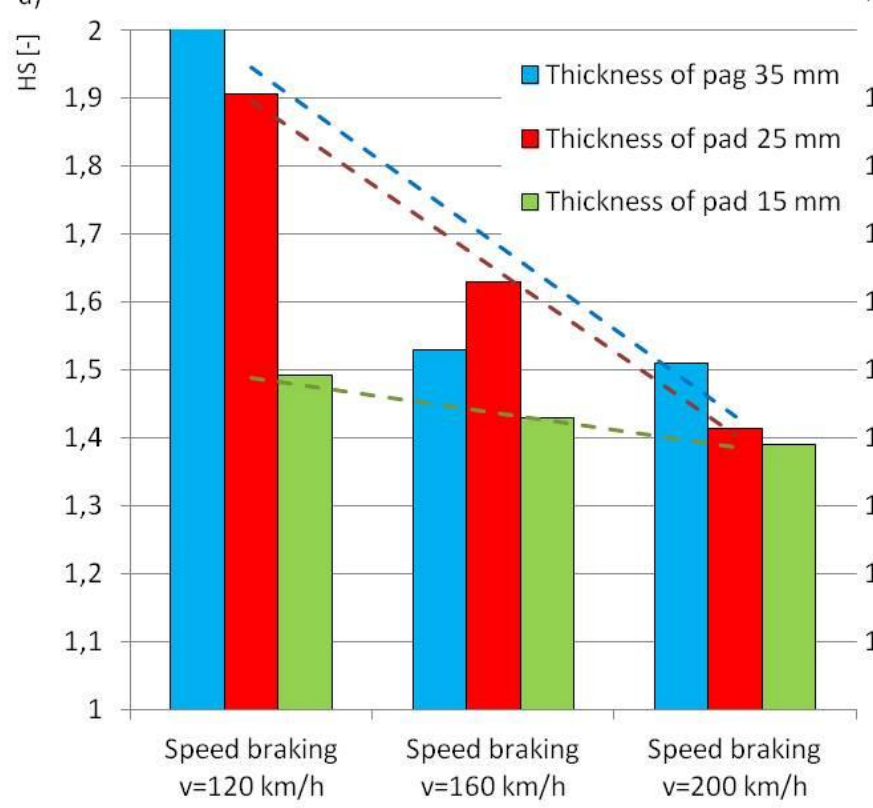

b)

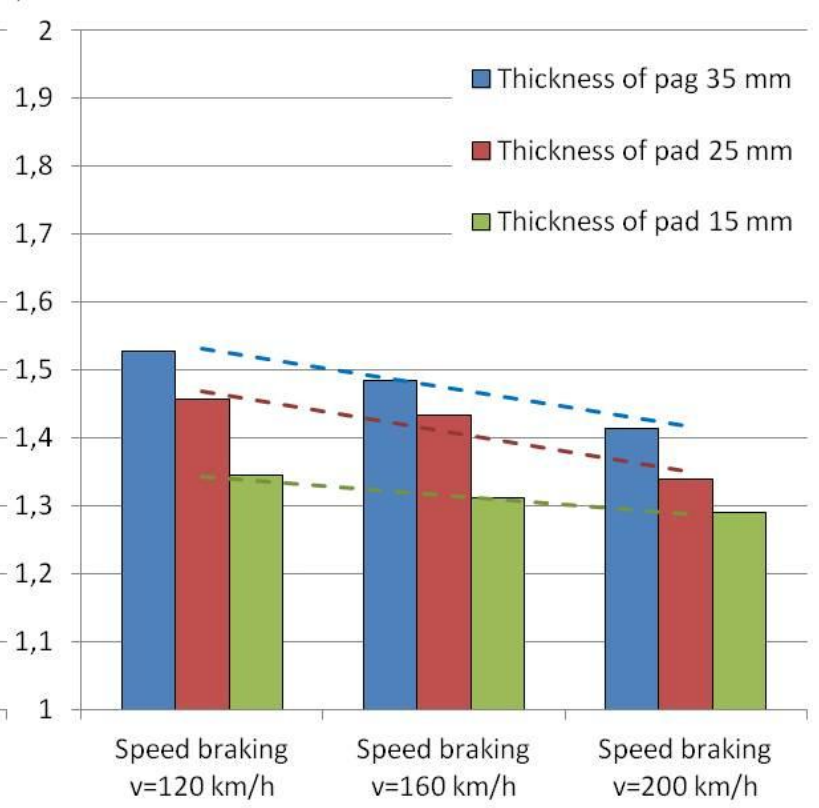

Fig. 9. Dependence value hot spots on the speed brake and the thickness of the friction pads of the braking pressure contact: a) $N=36 \mathrm{kN}$, b) $N=25 \mathrm{kN}$

Courses of $\Delta T$ at hotspots were approximated by linear functions for the selected speed brakes, the pressure and the thickness of the friction pads which is represented by the relationships (2-7).

$$
\begin{aligned}
& H S_{N=36 k N, G 1=35 \mathrm{~mm}}=-0,2566 v+2,2015 \quad R^{2}=0,78 \\
& H S_{N=36 k N, G 2=25 \mathrm{~mm}}=-0,2458 v+2,1417 \quad R^{2}=0,99 \\
& H S_{N=36 k N, G 3=15 \mathrm{~mm}}=-0,0502 v+1,5377 \quad R^{2}=0,98 \\
& H S_{N=25 k N, G 1=35 \mathrm{~mm}}=-0,057 v+1,589 \quad R^{2}=0,98 \\
& H S_{N=25 k N, G 2=25 \mathrm{~mm}}=-0,0589 v+1,5276 \quad R^{2}=0,89 \\
& H S_{N=25 k N, G 3=15 \mathrm{~mm}}=-0,0269 v+1,3692 \quad R^{2}=0,98
\end{aligned}
$$

By analyzing Figure 9 it is stated that the biggest increases in temperature (hot spots values) occur after braking from a speed of $v=120 \mathrm{~km} / \mathrm{h}$ on the new pads (with thickness of $35 \mathrm{~mm}$ ) and with pressure $\mathrm{N}=36 \mathrm{kN}$. Lower values at hotspots occur after braking from a speed of $v=200 \mathrm{~km} / \mathrm{h}$ even though the average value of the disc temperature is higher than after braking from $v=120 \mathrm{~km} / \mathrm{h}$. Dependencies (2-7) allow to estimate the value of hot spots for three breaking speeds, three thickness of the friction pads and two pressures of the pad to the disc with the coefficient of determination above 0.78 (the lowest $R^{2}$ value for the linear approximating function ).

In addition, by analyzing recorded thermal images, it was found that even at a lower pressure pads to the disc $\mathrm{N}=25 \mathrm{kN}$ while braking from $\mathrm{v}-120 \mathrm{~km} / \mathrm{h}$ hot spots are not observed. Only hot bands appear for which a maximum and minimum value of temperature has been assigned. It was done in order to calculate $\Delta T$ temperature rise. What is more, for the brakings from a speed of $v=160$ and $200 \mathrm{~km} / \mathrm{h}$ the phenomenon of hot spots do not occur regularly, but hot bands with slightly visible hot areas appear. 


\subsection{1/qirt.2016.115}

On the basis of the recorded videos by using the infrared camera a model of temperature distribution on the brake disc with a diameter of $590 \mathrm{~mm}$ was proposed. This disc brake is cooperates with the friction pad made of organic material. Figure 10 presents a model of a hot band formation (two of three) in the first two seconds of braking to two and then to one hot band in the last seconds of braking. In the case of implementation of the biggest pressure $\mathrm{N}=36 \mathrm{kN}$ in the last seconds hot spots can be most often observed in the vicinity of the inner radius.

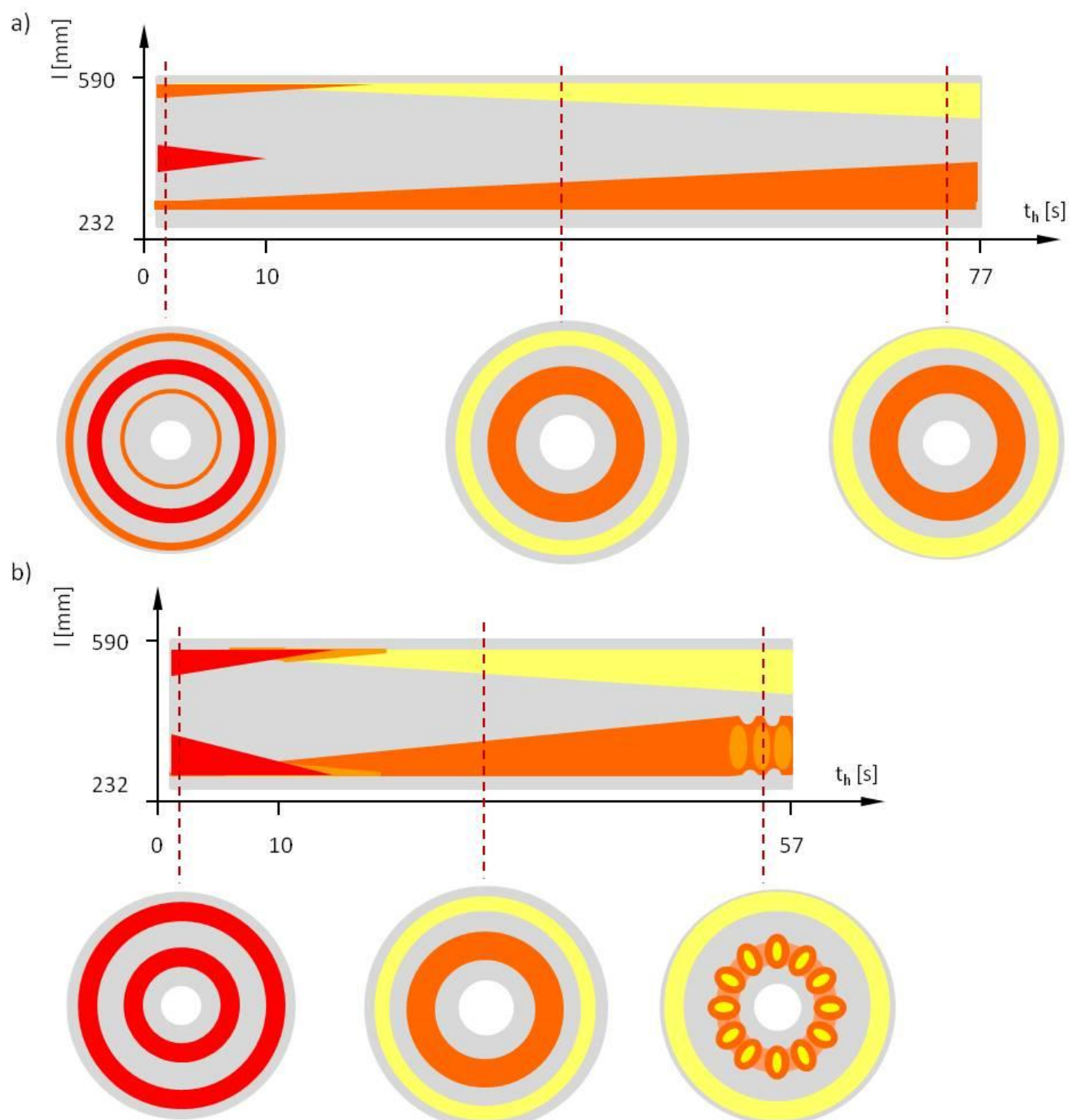

Fig. 10. Pressure distribution models of the pad to the brake disc based on the results of the thermal tests for braking speeds $200 \mathrm{~km} / \mathrm{h}$ : a) pressure contact $25 \mathrm{kN}$, b) pressure contact $36 \mathrm{kN}$

\section{Conclusions}

On the basis of conducted research and analysis the following conclusions can be put forward:

1. The organic material used for friction linings for railway brake discs with a diameter of $590 \mathrm{~mm}$ causes that the hot spots slightly exceed the value of 2 at the braking speed $v=200 \mathrm{~km} / \mathrm{h}$. In the case of friction pads made from sintered metal, and braking at the same speeds the hotspots on the basis of the studies in [13] amount to 8.

2. Hot areas (hot spots) occur only after braking from higher speeds (above $120 \mathrm{~km} / \mathrm{h}$ ). This was found when implementing the pressure to the disc $\mathrm{N}=36 \mathrm{kN}$. At lower speeds hot bands are observed. Their number changes during braking from three or four bands at the beginning of braking to one or two bands in the last 
seconds of deceleration. For smaller pressures of pad to the disc for example. $\mathrm{N}=25 \mathrm{kN}$ and for speed $\mathrm{v}=120$ $\mathrm{km} / \mathrm{h}$ hot spots are not observed. Hot areas are present only at the speed of 160 and $200 \mathrm{~km} / \mathrm{h}$.

3. The greater pressure of friction pads to the disc promotes the phenomenon hot spots formation (braking from $\mathrm{N}=36 \mathrm{kN}$ against the braking $\mathrm{N}=25 \mathrm{kN}$ ).

4. The research on organic linings have shown that higher values of hotspots occur after braking from a speed of $\mathrm{v}=120 \mathrm{~km} / \mathrm{h}$ than after braking from a speed of $\mathrm{v}=200 \mathrm{~km} / \mathrm{h}$. Although average values of disc temperature increases when the braking speed increases.

5. Braking on new (lapped) friction pads promotes the formation of the hot areas than in the case of worn pads. The organic material that belongs to the group of plastics, hinders the heat conducted to the further areas of the braking system. In this case, the brake housings. Previous studies have shown that the braking with worn pads slightly lower the value of the average brake disc temperature and raising the temperature of the brake holders.

6. The proposed linear regression models allow for the estimation of hotspots values for the value of hot spots for the three braking speeds and two pressures of the pads to the disc and for three thicknesses of the friction pads.

7. The phenomenon of hot spots, which resulted in irregular temperature rise on the disc is mainly a consequence of alternating pressure distribution of friction pads with a brake disc, as observed on the recorded videos by using the infrared camera.

The project is funded by the National Centre for Research and Development, program LIDER V, contract No. LIDER/022/359/L-5/13/NCBR/2014

\section{REFERENCES}

[1] Abbasi S., Teimourimanesh S., Vernersson T., Sellgren U., Olofsson U., Lundén R., Temperature and thermoelastic instability at tread braking using cast iron friction material. WEAR 314 (2014), pp. 171-180.

[2] Aranganathan N., Jayashree B., Development of copper-free eco-friendly brake-friction material using novel ingredients. WEAR 352-353 (2016), pp. 79-91.

[3] Belhocine A., Bouchetara M., Thermomechanical modelling of dry contacts in automotive disc brake. International Journal of Thermal Sciences 60 (2012), pp. 161-170.

[4] Grzes P., Oliferuk W., Adamowicz A., Kochanowski K., Wasilewski P., Yevtushenko A.A., The numericalexperimental scheme for the analysis of temperature field in a pad-disc braking system of a railway vehicle at single braking. International Communications in Heat and Mass Transfer 75 (2016), pp. 1-6.

[5] Kasem H., Brunel J.F., Dufrénoy P., Siroux M., Desmet B., Thermal levels and subsurface damage induced by the occurrence of hot spots during high-energy braking. WEAR 270 (2011), pp. 355-364.

[6] Kumar M., Boidin X., Desplanques Y., Bijwe J., Influence of various metallic fillers in friction materials on hotspot appearance during stop braking. WEAR 270 (2011), pp. 371-381.

[7] Li Z., Han J., Yang Z., Li W., Analyzing the mechanisms of thermal fatigue and phase change of steel used in brake discs. Engineering Failure Analysis 57 (2015), pp. 202-218.

[8] Panier S., Dufrénoy P., Weichert D, An experimental investigation of hot spots in railway disc brakes, Wear 256 (2004), pp. 764-773, 2004.

[9] Polska Norma PN-EN 14535-1, Kolejnictwo - tarcze hamulcowe kolejowych pojazdów szynowych - Część 1: Tarcze hamulcowe wtłaczane lub mocowane skurczowo na osiach zestawów tocznych lub napędnych, wymiary i wymagania dotyczące jakości, Warszawa 2006.

[10] Sobieski W., Termodynamika w eksperymentach Skrypt dla studentów. Olsztyn 2015, wydanie I 06.04.2016, [on-line] URL: http://pracownicy.uwm.edu.pl/wojsob/pliki/termodynamika/termodynamika.pdf, pp. 148.

[11] Website: http://www.railway-technology.com/projects/alfa/alfa7.html (05.05.2016).

[12] Więcek B, De Mey G., „Termowizja w podczerwieni podstawy i zastosowania”. Wydawnictwo PAK, Warszawa 2011, pp. 34-43.

[13] Wirth X., Improving the Performance of Disc Brakes on High-speed Rail Vehicles with a Novel Types of Brake Pad: Isobar. RTR no 1 (1998), pp. 24-29, 1998.

[14] Wu S.C., Zhang S.Q., Xu Z.W., Thermal crack growth-based fatigue life prediction due to braking for a highspeed railway brake disc. International Journal of Fatigue 87 (2016), pp. 359-369.

[15] Yan H.B., Zhang Q.C., Lu T.J., Heat transfer enhancement by X-type lattice in ventilated brake disc. International Journal of Thermal Sciences 107 (2016), pp. 39-55.

[16] Zagrodzki P., Truncone S.A., Generationof hot spots in a wet multidisc clutch during short-term engagement. Wear 254 (2003), pp. 474-491. 